\title{
ROLE OF FINE NEEDLE ASPIRATION CYTOLOGY IN DIAGNOSIS OF SALIVARY GLAND LESIONS
}

\author{
Surinder Kumar Atri1, Shweta Bhagat², Varinder Mohan Rana ${ }^{3}$, Kuldeep Singh ${ }^{4}$, Minakeshi Rana ${ }^{5}$
}

1Associate Professor, Department of Pathology, Government Medical College Jammu, Jammu \& Kashmir, India.

2Junior Resident, Department of Pathology, Government Medical College Jammu, Jammu \& Kashmir, India.

3 Demonstrator, Department of Pathology, Government Medical College Jammu, Jammu \& Kashmir, India.

4 Professor, Department of Pathology, Government Medical College Jammu, Jammu \& Kashmir, India.

${ }^{5}$ Consultant Gynaecology and Obstetrics, DH Samba; Jammu, J \& K Health Services, Jammu \& Kashmir, India.

ABSTRACT
BACKGROUND
nalivary glands are affected by a variety lesions which may be non-neoplastic such as inflammation (Sialadenitis), cysts or
neoplastic which includes both benign and malignant tumours. Except for acute infections which are usually painful, salivary gland
diseases rarely present with any symptoms during the early stages ${ }^{1}$

\section{MATERIALS AND METHODS}

A cross sectional study to evaluate the role of fine needle aspiration cytology in the diagnosis of salivary gland lesions in Department of Pathology, Government Medical College Jammu, Jammu \& Kashmir was done. All cases diagnosed in Department of Pathology as salivary gland lesions in cytopathology and histopathology sections from March 2015 to March 2016 were included in the study. Papanicolaou and May-Grunwald Giemsa stained slides of all these cases were reviewed and categorized/diagnosed. Of 156 FNAC cases, 102 had their corresponding histopathology reports. All these cases were retrieved from the histopathology section. $\mathrm{H} \& \mathrm{E}$ slides of all cases were reviewed, where required new H \& E slides from paraffin blocks were also made. All these were categorized and diagnosed as per latest guidelines. Clinical features and follow up data was obtained from the consult files of referring surgeon.

\section{RESULTS}

The age of patients ranged from 11 years to 80 years with the mean age being 42.7 years. Majority of the patients i.e. 94 out of 156 $(60.25 \%)$ were in the age group of 21-50 years. Male to female ratio was 1.3:1. Most of the patients presented with swelling in parotid region i.e. 104 (66.66 \%) followed by submandibular region 40 (25.64\%) and oral cavity 12 (7.69\%). Of the 156 cases, 38 $(24.35 \%)$ were diagnosed as inflammatory lesions and $114(73.07 \%)$ as neoplastic. Of the 38 inflammatory salivary gland lesions, sialadenitis was the most common lesion 18 cases (47.36\%), followed by sialadenosis, 8 cases (21.05\%). A total of 114 neoplastic lesions were diagnosed on fine needle aspiration cytology. Out of 114 cases, $92(80.70 \%)$ cases were benign tumours and 22 $(19.30 \%)$ cases were malignant tumours. 102 of 156 patients had their corresponding histopathological report. Histopathology of biopsy/ surgical specimen revealed that 68 (66.6\%) patients had benign lesions, 20 (19.60\%) had malignant lesions while 14 $(13.72 \%)$ patients had non-neoplastic lesions. FNA cytology findings were correlated with histopathology in cases where histopathology reports were available. In our study, sensitivity and specificity of FNAC is $99.02 \%$ and $99.20 \%$. Positive and negative predictive values are $96.6 \%$ and $98.14 \%$. Percentage of false negative is $1.01 \%$ and accuracy of FNAC is $98.68 \%$.

\section{CONCLUSION}

FNAC is a rapid, convenient and accurate method of tissue diagnosis that can be performed on outpatient basis. It is highly sensitive and specific technique for diagnosis of most salivary gland swellings.

\section{KEY WORDS}

Salivary Gland, FNAC, Neoplastic, Inflammatory.

HOW TO CITE THIS ARTICLE: Atri SK, Bhagat S, Rana VM et al. Role of fine needle aspiration cytology in diagnosis of salivary gland lesions. J. Evolution Med. Dent. Sci. 2019;8(14):1111-1116, DOI: 10.14260/jemds/2019/246

\section{BACKGROUND}

The salivary glands are affected by a variety of lesions which may be non-neoplastic such as inflammation (Sialadenitis), cysts or neoplastic which includes both benign and malignant tumours. Except for acute infections which are usually painful, salivary gland diseases rarely present any symptoms

'Financial or Other Competing Interest': None.

Submission 20-01-2019, Peer Review 11-02-2019,

Acceptance 14-02-2019, Published 08-04-2019.

Corresponding Author:

Dr. Minakeshi Rana,

Consultant Gynaecologist,

House No. 24, Lane 51, Behind Sunny Farms,

Greater Kailash Post Office, J \& K, India.

Gangyal, Jammu,

E-mail: surinderKumaratri@gmail.com

DOI: $10.14260 /$ jemds/2019/246

\section{(c) (i) $($ )}

during the early stages. ${ }^{1}$ Due to this, there is generally a long interval before the patient reports to hospital. Infections of the salivary glands are usually viral in origin, only a minority of cases are due to bacterial infection. Initiation and progression of salivary gland infections depends on the decrease in host resistance to infection and may be encountered secondary to a variety of predisposing conditions including trauma, immunosuppression, debilitation and local conditions such as duct obstruction by sialolithiasis, stricture or other pathology. ${ }^{2}$ Sialolithiasis is the main cause of unilateral diffuse parotid or submandibular swelling. ${ }^{2}$ Sialoliths are calcified organic matters that form within the secretory system of the major salivary glands. The sialoadenitis do occur whenever there is reduced salivary flow which results into retrograde infection of the glandular tissue via the salivary duct. Sialoadenitis can also be due to 
obstruction of the duct due to stone, common in submandibular glands. ${ }^{1}$ Other reactive lesions of salivary gland include mucocele, mucous retention cyst and extravasation cyst that commonly arises from the minor salivary glands. ${ }^{3}$ Mucocele have been reported in varying ages, but young age is more favoured from $10-20$ years with a slight male predilection. ${ }^{4}$ Favoured sites are the lower lip $(60-70 \%)$ and floor (6-15\%) of mouth.4,5 They usually present as painless swellings with bluish hue when mucin is near the surface, however when deep in the tissues they may be diffuse and covered by the normal mucosa without change in colour. Diagnosis is based principally on the clinical examination, radiographic findings and histological findings. ${ }^{4}$ HIV associated salivary gland disease, hepatitis C virus associated sialadenitis, drug associated salivary gland disease, granulomatous sialadenitis, nonspecific reactive changes, necrotizing sialometaplasia, Sjogren's syndrome and Mikulicz syndrome are other non- neoplastic salivary gland lesions.

Salivary gland tumours elicit considerable medical interest because of their multifaceted clinical presentation, varied histological appearance and the associated difficulties predicting their prognosis. ${ }^{6}$ The incidence ranges from $0.4-$ 13.5/lac population. ${ }^{7,8}$ Salivary gland tumours arise from the superficial lobe and present as facial swellings. Tumours that occur in the deep lobe often expand through the parapharyngeal space manifesting as oropharyngeal swelling 9 . Although salivary gland tumours are rare, they account for 2-6.5\% of all the head and neck tumours. ${ }^{8}$ Benign tumours, occurring most commonly include pleomorphic adenoma, Warthin's tumour, oncocytoma etc. while malignant tumours include mucoepidermoid carcinoma, adenoid cystic carcinoma, and acinic cell carcinoma etc. Pleomorphic adenoma, a benign mixed tumour is the most commonly reported benign tumour of the major and minor salivary glands worldwide. ${ }^{10}$ The commonest site for pleomorphic adenoma is the parotid gland followed by the minor salivary glands. ${ }^{11,12}$ However this has also been reported in ectopic salivary gland sites, such as neck, nose cervical lymph nodes and the parapharyngeal spaces. ${ }^{12}$ Warthin's tumour or papillary cystadenoma lymphomatosum is the most common salivary gland occurring between fifth and eighth decades of life 10 and accounting for approximately $5-6 \%$ of epithelial salivary gland neoplasms. It is almost exclusively a tumour of parotid gland and peri parotid lymph nodes.

Malignant tumours comprise $15-30 \%$ of all parotid tumours, $40 \%$ of submandibular gland tumours, $70-90 \%$ of sublingual and over $50 \%$ of minor salivary gland tumours. Thus, the likelihood of a salivary gland tumour being malignant is more or less inversely proportional to the size of the gland.13 Between 64- 80\% of all primary epithelial tumours occur in parotid glands, $7-11 \%$ occur in the submandibular glands, less than $1 \%$ occur in the sublingual glands and $9-23 \%$ occur in the minor glands. ${ }^{14}$ Mucoepidermoid carcinoma is the most common malignant neoplasm of the major and minor salivary glands in adults and children accounting for $4.06 \%$ of tumours. Adenoid cystic carcinoma is the second most common salivary gland tumour, accounting for $1.63 \%$ of all salivary gland neoplasms. It is a slow growing but aggressive tumour of the submandibular and minor salivary glands and has tendency for distant metastasis. ${ }^{15}$ Lesions mimicking salivary gland tumours can arise in tissues close to the salivary glands such as lymph nodes, soft tissue and skin. ${ }^{16}$ Differential diagnosis of these masses on clinical examination are salivary gland tumours, inflammatory process and enlarged lymph nodes. Thus, a mass in the salivary gland region presents as a diagnostic challenge with regard to its site of origin, histological behaviour and tissue diagnosis.17,18 In routine practice usually a incisional or excisional biopsy is done for which patient has to admitted in hospital, worked up anaesthesia and then taken to operation theatre and then for histopathology it takes 3-4 days. Whereas FNAC is a OPD procedure and patient can be sent back home. Moreover fine needle aspiration cytology has emerged as the most widely accepted diagnostic tool for salivary gland lesions, due to their superficial location and easy accessibility. ${ }^{19}$ Fine needle aspiration cytology is accurate, simple, rapid, inexpensive, well tolerated and harmless procedure for the patient. ${ }^{8}$ Therefore we planned this study to see whether fine needle aspiration in can be used to type salivary gland lesions as benign and malignant. So that patients are taken up for surgery depending upon the diagnosis of FNAC.

\section{MATERIALS AND METHODS}

It is an observational study. All cases of salivary gland lesions diagnosed in FNA cytology and surgical pathology sections of Department of Pathology from January 2016 to Dec. 2017 were retrieved from cytology and consult files of Govt. Medical College, Jammu. In cytology section 156 cases were identified over a period of two years. Papanicolaou and MayGrunwald Giemsa stained slides of all these cases of salivary gland lesions were reviewed and categorized/diagnosed as per the recent guidelines. Of 156 cases, 102 had their corresponding histopathology reports. All these cases were retrieved from the histopathology section. $\mathrm{H} \& \mathrm{E}$ slides of all cases were reviewed, where required new $\mathrm{H} \& \mathrm{E}$ slides from paraffin blocks were also made. All these were categorized and diagnosed as per latest guidelines. Clinical features and follow up data were obtained from the consult files of referring surgeons. Statistical analysis was performed using SPSS 10.0 for windows student version (SPSS Inc. 233 South Wacker Drive, 11th Floor, Chicago, IL 60606-6412). Standard variables of specificity, sensitivity and predictive value were also applied.

\section{RESULTS}

The age of patients ranged from 11 year to 80 year with the mean age being 42.7 year. Majority of the patients i.e. 94 out of $156(60.25 \%)$ were in the age group of 21-50 years. Male female ratio was 1.3: 1 . Most of the patients presented with swelling in parotid region i.e. $104(66.66 \%)$ followed by submandibular region $40(25.64 \%)$ and oral cavity 12 (7.69\%). Most of the swellings were non - tender: 132 (88.46 $\%)$ were non-tender and 18 (11.53 \%) were tender. Parotid gland was the most commonly involved site 106 (67.94\%) followed by submandibular gland 38 (24.35\%) sublingual gland 1 (1.28\%) and minor salivary glands in 5 (6.41\%). Cytology diagnosis was divided into inflammatory and neoplastic lesions

\section{Inflammatory Lesions}

Of the 156 cases, 38 (24.35\%) were diagnosed as inflammatory lesions and $114(73.07 \%)$ as neoplastic lesions. 
Four cases had inadequate material for evaluation. Of the 38 inflammatory salivary gland lesions, sialadenitis was the most common lesion: 18 cases $(47.36 \%)$ followed by by sialadenosis: 8 cases (21.05\%), chronic non-specific reactive hyperplasia [Intra-parotid lymph node]: 6 cases (15.78\%), non - neoplastic cysts: 4 cases (10.25\%) and two cases of abscess. All cases of sialadenitis were in submandibular gland, sialadenosis was encountered equally in submandibular and parotid gland. Non- neoplastic cysts were seen in parotid gland and minor salivary gland. Chronic reactive hyperplasia was seen in parotid and submandibular glands. Two cases of abscess were seen in parotid gland.

\begin{tabular}{|c|c|c|}
\hline FNAC Diagnosis & Number of Cases & Percentage \\
\hline Sialadenitis & 18 & $47.36 \%$ \\
\hline Sialadenosis & 08 & $21.05 \%$ \\
\hline $\begin{array}{c}\text { Reactive Lymphoid } \\
\text { Hyperplasia } \\
\end{array}$ & 06 & $15.78 \%$ \\
\hline Non- Neoplastic Cysts & 04 & $10.52 \%$ \\
\hline Abscess & 02 & 5.26 \\
\hline Total & 38 & $100 \%$ \\
\hline \multicolumn{3}{|c|}{ Table 1. Table Showing Inflammatory Lesions } \\
\hline
\end{tabular}

\section{Neoplastic Lesions}

A total of 114 neoplastic lesions were diagnosed on fine needle aspirate. Out of 114 cases, $92(80.70 \%)$ cases were benign tumours and $22(19.30 \%)$ cases were malignant tumours. Among the benign tumours, pleomorphic adenoma was the most common tumour, accounting for $70(61.40 \%)$ cases followed by Warthin's tumour constituting 20 (17.54 $\%)$ cases. Mucoepidermoid carcinoma was the most common malignant tumour constituting 8 (7.01\%) cases followed by 6 $(5.26 \%)$ cases of adenocarcinoma, $4(3.50 \%)$ cases of acinic cell carcinoma and two case each of adenoid cystic carcinoma and Non-Hodgkin's lymphoma. Pleomorphic adenoma was seen in the $3^{\text {rd }}$ to $5^{\text {th }}$ decade where as Warthin's tumour was seen in 40 - 80 a year age group. In contrast malignant tumours were seen in patients older than 50 years age except for two case each of mucoepidermoid carcinoma and polymorphous low-grade adenocarcinoma which were seen $2^{\text {nd }}$ decade of life. The neoplastic lesions showed male preponderance with a male to female ratio $1.1: 1$ but in Warthin's tumour more male predominance was observed with ratio of 4:1. Out of 114 neoplastic lesions, parotid gland was most common site observed with 90 (78.94\%) cases followed by $14(12.28 \%)$ cases in submandibular glands, 8 $(7.01 \%)$ cases in minor salivary glands and two cases $(1.75 \%)$ involving sublingual gland respectively. Out of 92 benign tumours, 70 cases were diagnosed as pleomorphic adenoma accounting for $59.64 \%$ cases. Most of them were found to be involving the parotid gland ( 58 case) followed by submandibular gland ( 6 cases), minor salivary gland ( 4 cases) and sublingual gland (2 case). Warthin's tumour accounted for $20(17.54 \%)$ cases, 16 out of 20 were in parotid gland and the remaining 4 cases were seen in submandibular gland. Two cases of basal cell adenoma were seen involving the parotid gland $(1.75 \%)$. Mucoepidermoid carcinoma, the most common malignant tumour in the present study, was found to involve parotid gland in six cases out of $8(7.01 \%)$ cases and two cases were in minor salivary glands.
Adenocarcinoma was diagnosed in 6 (5.45\%) cases involving parotid gland in 4 cases and submandibular gland in two cases. Acinic cell carcinoma was diagnosed in 4 (3.50\%) cases, 2 cases each were seen in parotid and submandibular glands. Two cases of adenoid cystic carcinoma were diagnosed involving the minor salivary glands. Two cases of Non- Hodgkin's lymphoma were also diagnosed involving parotid gland.

\begin{tabular}{|c|c|c|}
\hline FNAC Diagnosis & No. of Cases & Percentage \\
\hline Pleomorphic Adenoma & 70 & $61.40 \%$ \\
\hline Warthin's Tumour & 20 & $17.54 \%$ \\
\hline Basal Cell Adenoma & 02 & $1.75 \%$ \\
\hline Mucoepidermoid Carcinoma & 08 & $7.01 \%$ \\
\hline Adenocarcinoma & 06 & $5.26 \%$ \\
\hline Acinic Cell Carcinoma & 04 & $3.50 \%$ \\
\hline Adenoid Cystic Carcinoma & 02 & $1.75 \%$ \\
\hline NHL & 02 & $1.75 \&$ \\
\hline Total & 114 & $100 \%$ \\
\hline
\end{tabular}

\section{Analysis of Result of Histology}

102 of 156 patients had their corresponding histopathological report. Histopathology of biopsy/ surgical specimen revealed that 68 (66.6\%) patients had benign lesions, 20 (19.60\%) had malignant lesions while 14 $(13.72 \%)$ patients had non-neoplastic lesions. In nonneoplastic lesions there were 10 cases of sialadenitis and two cases each of mucocele and lymphoepithelial cyst. Results of benign and malignant lesions are shown in tables given below.

\begin{tabular}{|c|c|c|c|}
\hline Sr. No. & Histology Dx & No. of Cases & Percentage \\
\hline 1. & Pleomorphic Adenoma & 48 & 47.05 \\
\hline 2. & Schwannoma & 02 & 1.96 \\
\hline 3. & Warthin's Tumour & 14 & 13.72 \\
\hline 4. & Basal Cell Adenoma & 02 & 1.96 \\
\hline 5. & Papillary Cystadenoma & 02 & 1.96 \\
\hline \multicolumn{4}{|c|}{ Table 3. Table Showing Different Benign Lesions on } \\
Histopathology \\
\hline
\end{tabular}

\begin{tabular}{|c|c|c|c|}
\hline Sr. No. & Histology Dx & No. of Cases & Percentage \\
\hline 1. & $\begin{array}{c}\text { Mucoepidermoid } \\
\text { Carcinoma }\end{array}$ & 08 & 7.84 \\
\hline 2. & Adenocarcinoma & 04 & 3.92 \\
\hline 3. & Acinic Cell Carcinoma & 04 & 3.92 \\
\hline 4. & Adenoid Cystic Carcinoma & 02 & 1.96 \\
\hline 5. & Non-Hodgkin's Lymphoma & 02 & 1.96 \\
\hline \multicolumn{3}{|c|}{ Table 4. Table Showing Different Malignant Lesions on } \\
Histopathology \\
\hline
\end{tabular}

Cytohistological correlation: FNA cytology findings were correlated with histopathology in cases where histopathology reports were available. All 5 cases of sialadenitis correlated with histopathology. Four cases of non-neoplastic cysts reported on FNAC were diagnosed as two cases of each mucocele and lymphoepithelial cyst on histopathology.

Cytohistological correlation of benign and malignant lesions is table $5 \& 6$. 


\begin{tabular}{|c|c|c|c|c|}
\hline FNAC Dx & $\begin{array}{c}\text { No. of } \\
\text { Cases }\end{array}$ & $\begin{array}{c}\text { Histology } \\
\text { Dx }\end{array}$ & $\begin{array}{c}\text { No. of } \\
\text { Cases }\end{array}$ & Remarks \\
\hline $\begin{array}{c}\text { Pleomorphic } \\
\text { Adenoma }\end{array}$ & 52 & $\begin{array}{c}\text { Pleomorphic } \\
\text { Adenoma } \\
\text { Schwannoma } \\
\text { Mucoepidermoid } \\
\text { Carcinoma }\end{array}$ & $\begin{array}{c}48 \\
02\end{array}$ & $\begin{array}{c}\text { TP } \\
\text { TP } \\
\text { FN }\end{array}$ \\
\hline $\begin{array}{c}\text { Warthin's } \\
\text { Tumour }\end{array}$ & 14 & $\begin{array}{c}\text { Warthin's } \\
\text { Tumour }\end{array}$ & 14 & TP \\
\hline $\begin{array}{c}\text { Basal Cell } \\
\text { Adenoma }\end{array}$ & 02 & $\begin{array}{c}\text { Basal Cell } \\
\text { Adenoma }\end{array}$ & 02 & TP \\
\hline \multicolumn{4}{|r|}{ Table 5. Cytohistology Correlation of Benign Tumours } \\
\hline \multicolumn{4}{|r|}{ TP: True positive, FN: False negative } \\
\hline
\end{tabular}

\begin{tabular}{|c|c|c|c|c|}
\hline FNAC Dx & $\begin{array}{l}\text { No. of } \\
\text { Cases }\end{array}$ & Histology Dx & $\begin{array}{l}\text { No. of } \\
\text { Cases }\end{array}$ & $\begin{array}{c}\text { Re- } \\
\text { marks }\end{array}$ \\
\hline $\begin{array}{l}\text { Mucoepidermoid } \\
\text { Carcinoma }\end{array}$ & 08 & \begin{tabular}{|l} 
Mucoepidermoid \\
Carcinoma \\
Papillary \\
Cystadenoma \\
Squamous Cell \\
Carcinoma \\
\end{tabular} & $\begin{array}{l}04 \\
02 \\
02\end{array}$ & $\begin{array}{l}\text { TP } \\
\text { TP } \\
\text { FN }\end{array}$ \\
\hline $\begin{array}{c}\text { Polymorphous } \\
\text { Low-Grade } \\
\text { Adenocarcinoma } \\
\text { Adenocarcinoma } \\
\text { NOS } \\
\end{array}$ & 04 & \begin{tabular}{|c|} 
Polymorphous \\
Low-Grade \\
Adenocarcinoma \\
Mucoepidermoid \\
Carcinoma \\
\end{tabular} & 02 & $\mathrm{TP}$ \\
\hline $\begin{array}{l}\text { Non- Hodgkin's } \\
\text { Lymphoma }\end{array}$ & 02 & $\begin{array}{c}\text { Non- Hodgkin's } \\
\text { Lymphoma }\end{array}$ & 02 & $\mathrm{TP}$ \\
\hline $\begin{array}{l}\text { Adenoid Cystic } \\
\text { Carcinoma }\end{array}$ & 02 & & 02 & $\mathrm{TP}$ \\
\hline $\begin{array}{l}\text { Acinic Cell } \\
\text { Carcinoma }\end{array}$ & 04 & & 04 & $\mathrm{TP}$ \\
\hline
\end{tabular}

Thus, out of 88 neoplastic lesions reported on FNAC, 84 were true positive, 2 false negative and 2 false positive.

\begin{tabular}{|c|c|c|}
\hline Test & Disease & No Disease \\
\hline Positive & 14 (True Positive) & 0 (False Positive) \\
\hline Negative & 88 (True Negative) & 0 (False Negative) \\
\hline Table 7. Cytohistological Correlation in Terms of True \\
Positive \& False Positive of Non-Neoplastic Lesions \\
\hline
\end{tabular}

\begin{tabular}{|l|c|c|}
\hline Test & Disease & No Disease \\
\hline Positive & 66 (True Positive) & 0 (False Positive) \\
\hline Negative & 34 (True Negative) & 2 (False Negative) \\
\hline \multicolumn{3}{|c|}{ Table 8. Cytohistological Correlation in Terms of True } \\
Positive \& False Positive of Benign Neoplastic Lesions \\
\hline
\end{tabular}

\begin{tabular}{|c|c|c|}
\hline Test & Disease & No Disease \\
\hline Positive & 18 (True Positive) & 2 (False Positive) \\
\hline Negative & 82 (True Negative) & 0 (False Negative) \\
\hline \multicolumn{3}{|c|}{ Table 9. Cytohistological Correlation in Terms of True } \\
Positive \& False Positive of Malignant Neoplastic Lesions \\
\hline
\end{tabular}

Thus in our study sensitivity and specificity of FNAC is 99.02\% and $99.20 \%$. Positive and negative predictive values are $96.6 \%$ and $98.14 \%$. Percentage of false negative is $1.01 \%$ and accuracy of FNAC is $98.68 \%$.

\section{DISCUSSION}

Salivary gland lesions can arise from a number of aetiologies including inflammatory processes, cysts and tumours.
Lesions mimicking salivary gland tumours can arise in tissue close to the gland, such as lymph nodes, soft tissue and skin.16,20 Clinical examination of the salivary glands can be inaccurate in distinguishing between salivary gland tumours and inflammatory processes. ${ }^{20,21}$ Thus a mass in the region of the salivary gland presents a diagnostic challenge with regards to its site of origin, histological behaviour and tissue diagnosis.

Fine needle aspiration cytology (FNAC) plays a vital role in the evaluation of the salivary gland lesions, especially in a developing country like India where the cost of hospital stay and medical expenses are often not affordable by the patients. The age of patients in our study ranged from 11 year to 80 year with the mean age being 42.7 year and maximum incidence was in $5^{\text {th }}$ to 7 th decade which is comparable with other studies.8,20,21 The male female ratio in our study was 1.3: 1 which is comparable with other studies7, 22, 23. In our study the parotid gland swelling was the most common clinical presentation of salivary gland lesions which is comparable with other studies. ${ }^{8,22,24}$ In our study inflammatory lesions were $25 \%$ and neoplastic lesions were $75 \%$ which is comparable to the study conducted by Khandekar MM et al. ${ }^{25}$ But other studies by Singh A et al ${ }^{21}$ and Gandhi SH et al ${ }^{7}$ showed a higher incidence of non- neoplastic lesions. In our study sialadenitis was the most common non neoplastic lesion, 18 cases $(47.36 \%)$ involving the submandibular gland mainly and found to be in the age group of $3^{\text {rd }}$ to $8^{\text {th }}$ decade of life which is almost similar to the study by Jain $\mathrm{R}$ et al. ${ }^{26}$ In our study the ratio of ratio of benign and malignant lesions is similar to other studies.7,20,25 In our study, the most common site of neoplastic lesions is parotid gland followed by submandibular gland which is similar to the study by Sengupta S et al27 and Gandhi SH et al.7 In our study most common benign tumour pleomorphic adenoma accounting for $59.64 \%$ cases, and maximum number of cases were seen in $5^{\text {th }}$ to $7^{\text {th }}$ decade, followed by Warthin's tumour which accounted for 20 ( $17.54 \%$ ) cases, 16 out of 20 were in parotid gland and the remaining 4 cases were seen in submandibular gland. Two cases of basal cell adenoma were seen involving the parotid gland (1.75\%). This corroborated well with other studies. $7,20,21$ There has been a variation in the reported occurrence of malignant salivary gland tumours. Mucoepidermoid carcinoma, the most common malignant tumour in the present study, was found in $5^{\text {th }}$ to 7 th decade and involved parotid gland in six cases out of $8(7.01 \%)$ cases and two cases were in minor salivary glands. The youngest patient of mucoepidermoid carcinoma was 11-year-old female. The above results are comparable with other studies. ${ }^{7,20}$ Adenocarcinoma was diagnosed in 6 (5.45\%) cases involving parotid gland in 4 cases and submandibular gland in two cases which is comparable to the study Atarbashi MS et al.28 Acinic cell carcinoma was diagnosed in 4 $(3.50 \%)$ cases, 2 cases each were seen in parotid and submandibular glands and was seen in $3^{\text {rd }}$ and $5^{\text {th }}$ decade which is similar to the study conducted by Fernandes GC et al.15 Two case of adenoid cystic carcinoma were diagnosed involving the minor salivary glands which are also similar to other studies ${ }^{15}$. Two cases of Non- Hodgkin's lymphoma were also diagnosed involving parotid gland. On cytohistopathological correlation mucoepidermoid carcinoma was the most common tumour. These findings are similar to the studies conducted by Vaidya $S$ et. al.21 And 
Singh a et. al. ${ }^{20}$ The second most common tumour is adenocarcinoma which correlates with the finding of Stewart FW et. al. ${ }^{29}$ On literature review, the sensitivity of salivary gland FNAC ranges from $80-98 \%$ and specificity from $80-$ $100 \%$. In our study sensitivity and specificity of FNAC is $99.02 \%$ and $99.20 \%$ and accuracy is $98.68 \%$ which is close to the study reported by Gandhi SH et. al.7 Ersoz C et. al. ${ }^{30}$ And comparable to other studies. The positive predictive value and negative predictive value in our study are $96.66 \%$ and $98.14 \%$ respectively which are comparable to other studies. ${ }^{21,31,32}$ FNAC is a commonly accepted, sensitive and specific technique in the diagnosis of both neoplastic and non-neoplastic lesions of salivary gland. Hence, cytology can clearly distinguish between salivary and non-salivary gland lesions, benign and malignant tumours, and also specific and non-specific inflammation. Thus, it provides a decisive direction for therapeutic management of the patient. FNAC is a utility tool for subtyping of salivary gland lesions with variable specificity and sensitivity. ${ }^{25}$

\section{CONCLUSION}

FNAC is a rapid, convenient and accurate method of tissue diagnosis that can be performed on outpatient basis. It is highly sensitive and specific technique for diagnosis of most salivary gland swellings. Despite its limitations, salivary gland FNAC is simple, safe, reliable and remains a powerful diagnostic tool for salivary lesions.

\section{REFERENCES}

[1] Porter SR. Non neoplastic salivary gland diseases. In: Gleeson M, edr. Scott-Brown's Otolaryngology, Head and Neck surgery. $6^{\text {th }}$ edn. London: Hodder Arnold 1997: p. 1898-916.

[2] Masanja MI, Kalyanyama BM, Simon EN. Salivary gland tumours in Tanzania. East African Medical Journal 2003;80(8):429-34.

[3] Anastassov GE, Haiavy J, Solodnik P, et al. Submandibular gland mucocele: diagnosis and management. Oral Surg Oral Med Oral Pathol Oral Oral Radiol Endod 2000;89(2):159-63.

[4] Yague-Garcia J, Espana-Tost AJ, Berini-Aytes LB, et al. Treatment of oral mucocele - scalpel versus CO2 laser. Med Oral Pathol Oral Cir Bucal 2009;14(9):e469-74.

[5] Roeidiger WEW, Lloyd P, Lawson HH. Mucous extravasation theory as a cause of plunging ranulas. $\mathrm{Br}$ J Surg 1973;60(9):720-2.

[6] Huvos AG, Paulino HA. Salivary gland lesions. In: Mills SE, Carter D, Greenson JK, et al. eds. Sternberg's diagnostic surgical pathology. $4^{\text {th }}$ edn. New York: Lippincott William \& Wilkins 2004: p. 933-62.

[7] Gandhi SH, Purohit TM, Purohit MB, et al. FNAC diagnosis of salivary gland lesions with histopathological co-relation. NJIRM 2013;4(3):70-7.

[8] Agravat AH, Dhruva GA, Pujara KM, et al. Role of fine needle aspiration cytology in salivary glands pathology and its histopathological correlation: a two year prospective study in Western India. Online J Health Allied Sci 2012;11(3):5-8.

[9] Cheuk JW. Salivary gland lesion. In: Fletcher C, edr. Diagnostic histopathology of tumours. $3^{\text {rd }}$ edn. New York: Churchill Livingstone 2005: p. 239-324.
[10] Regezi JA, Sciuba JJ. Cysts of the oral region. In: Regezi JA, Sciuba JJ, eds. Oral pathology: clinical pathologic correlations. $3^{\text {rd }}$ edn. Philadelphia: Saunders 1999:p. 288.

[11] Vuhahula EA. Salivary gland tumours in Uganda: clinical pathological study. Afr Health Sci 2004;4(1):15-23.

[12] Otoh EC, Johnson NW, Olasoji H, et al. Salivary gland neoplasms in Maiduguri, North-Eastern Nigeria. Oral Dis 2005;11(6):386-91.

[13] Lingen MW, Kumar V. Head and Neck. In: Kumar V, Abbas AK, Fausto N, et al. eds. Robbins and Cotran pathologic basis of disease. $7^{\text {th }}$ edn. New Delhi: Elsevier 2007: p. 773-95.

[14] Christopher DM, Fletcher C. Salivary gland lesion. In: Diagnostic histopathology of tumours. $2^{\text {nd }}$ edn. New York: Churchill Livingstone 2000: p. 239-316.

[15] Fernandes GC, Pandit AA. Diagnosis of salivary gland tumours by FNAC. Bombay Hosp J 2000;42:108-11.

[16] Chan MK, McGuire LJ. Cytodiagnosis of lesions presenting as salivary gland swellings: a report of seven cases. Diagn Cytopathol 1992;8(6):439-43.

[17] Das DK, Nayak NC. Diagnosis of Langerhans cell histiocytosis by fine needle aspiration cytology. Acta Cytol 1995;39(6):1260-3.

[18] Das DK, Petkar MA, Al-Mane NM, et al. Role of fine needle aspiration cytology in the diagnosis of swellings in the salivary gland regions: a study of 712 cases. Med Princ Pract 2004;13(2):95-106.

[19] Kumar YS, Permi HS, Paramesha, et al. Role of fine needle aspiration cytology in salivary gland tumours in correlation with histopathology: a two year prospective study. J Clin Diagn Res 2011;5(7):137580.

[20] Singh A, Haritwal A, Murali BM. Correlation between cytology and histopathology of the salivary gland. Australasian Med J 2011;4(2):66-71.

[21] Zurrida S, Alasio L, Tradati N, et al. Fine needle aspiration of parotid masses. Am Cancer Soc 1993;72(8):2306-11.

[22] Choudhury AA, Sultana T, Siddique BH, et al. Diagnosis of parotid gland mass by the Fine Needle Aspiration Cytology (FNAC) and its histopathological correlation - 2 years study in BSMMU, Dhaka. BSMMU J 2011;4(2):65-9.

[23] Raval A, Goswami H, Parikh U, et al. Fine Needle Aspiration Cytology - as a diagnostic tool in salivary gland lesions. IJCRR 2014;6(7):17-25.

[24] Tahoun N, Ezzat N. Diagnostic accuracy and pitfalls of preoperative fine needle aspiration cytology in salivary gland lesions. J Egyptian Nat Cancer Institute 2008;20(4):358-68.

[25] Khandekar MM, Kavatkar AN, Patankar SA, et al. FNAC of salivary gland lesions with histopathological correlation. Ind J of Otolaryngology and Head and Neck Surgery 2006;58(3):246-8.

[26] Jain R, Gupta R, Kudesia $M$, et al. Fine needle aspiration cytology in the diagnosis of salivary gland lesions: a study with histologic comparison. Cytojournal 2013;10:5. 
[27] Senguptal S, Roy A, Mallick MC, et al. F.N.A.C. of salivary glands. Indian Journal of Otolaryngology and Head and Neck Surgery 2002;54(3):184-8.

[28] Moghadam SA, Moghadam FA, Dadfar M. Epithelial salivary gland tumours in Avhaz, Southwest of Iran. J Dent Res Dent Clin Dent Prospect 2010;4(4):120-3.

[29] Stewart FW. The diagnosis of tumours by aspiration. Am J Pathol 1933;(Suppl 9):801-12.3.

[30] Ersoz C, Uguz AH, Tuncer U, et al. Fine needle aspiration cytology of the salivary glands: a twelve years' experience. Aegean Path J 2004;1:51-6.
[31] Omhare A, Singh SK, Nigam JS, et al. Cytohistopathological study of salivary gland lesion in Bhundelkhand Region, Uttar Pradesh India. Article ID 804265, Pathology Research International 2014;2014:1-5.

[32] Ul Aan, Tanwani AK. Pitfalls in salivary gland fineneedle aspiration cytology. International Journal of Pathology 2009;7(2):61-5. 